\title{
TUJUAN PENDIDIKAN ISLAM DALAM MEMBANGUN KARATER SISWA DI ERA DIGITAL (Studi Analisis Pemikiran Pendidikan Islam Abuddin Nata)
}

\section{Ilma Ayunina}

Fakultas Agama Islam Universitas Wiralodra

E-Mail:ilmaayunina26@gmail.com

\section{Kambali}

Fakultas Agama Islam Universitas Wiralodra

E-Mail:kambaliibnu@gmail.com

\section{Akhmad Mujani}

Fakultas Agama Islam Universitas Wiralodra

E-Mail:akhmadmujani@gmail.com

\begin{tabular}{|c|c|c|}
\hline Received & Revised & Accepted \\
\hline 4 July 2019 & 2 Agustus 2019 & 20 Agustus 2019 \\
\hline
\end{tabular}

\section{THE OBJECTIVE OS ISLAMIC EDUCATION IN BUILDING STUDENT CHARACTER IN DIGITAL ERA (Analysis Study of Islamic Education in Abuddin Nata Perspective)}

\begin{abstract}
This study aims to explore the objectives of Islamic education in building student character in the digital era based on the study of Prof. Dr. H. Abudinata. The research method was library research by descriptive qualitative. The results showed that The purpose of Islamic education according to Prof. Dr. H. Abuddin Nata, M.A., can be formulated to foster and direct so that humans have the potential to do good, have faith and submit to Allah SWT, Therefore the aim of Islamic education is directed at efforts to shape humans so that they have good character and character. Noble character or good character is the main goal in Islamic education. The purpose of Islamic education in building the character of students in this digital era is to provide direction to students about technological advances that are very rapid
\end{abstract}


and so as not to be misdirected in using all the facilities provided in the digital era of Islamic education is one of the materials aimed at increasing noble character and values spiritual values in children.

Keywords: Islamic education, student character, and digital era.

\begin{abstract}
Abstrak
Penelitian ini bertujuan untuk mengeksplorasi tujuan pendidikan islam dalam membangun karakter siswa di era digitan berdasarkan studi pemikiran Prof. Dr. H. Abudinata. Metode penelitian studi pustaka (library research) deskriptif kualitatif. Tujuan pendidikan Islam menurut Prof. Dr. H. Abuddin Nata, M.A., yaitu dapat dirumuskan untuk membina dan mengarahkan agar msnusia berpotensi untuk berbuat baik, beriman dan tunduk kepada Allah SWT, Maka dari itu tujuan pendidikan Islam diarahkan pada upaya membentuk manusia supaya memiliki akhlak dan karakter yang baik. Akhlak mulia atau karakter yang baik merupakan tujuan pokok dalam pendidikan Islam. Tujuan pendidikan Islam dalam membangun karakter siswa di era digital ini untuk memberikan arahan terhadap peserta didik tentang kemajuan teknologi yang sangat pesat dan agar tidak salah arah dalam menggunakan semua fasilitias yang disediakan pada era digital pendidikan Islam merupakan salah satu materi yang bertujuan meningkatkan akhlak mulia serta nilainilai spiritual dalam diri anak.
\end{abstract}

Kata kunci: pendidikan islam, karakter siswa, dan era digital.

\title{
Pendahuluan
}

Pendidikan Islam menurut Abuddin Nata yaitu suatu pendidikan yang dalam pelaksanaannya berdasarkan pada ajaran Islam yang bersumber pada Al-qur'an, alSunnah, dengan demikian perbedaan pendidikan Islam dengan pendidikan lainnya ditentukan dengan adanya dasar ajaran Islam tersebut ${ }^{1}$. Maka tujuan pendidikan Islam tidak keluar dari kerangka ini, yaitu mempersiapkan manusia untuk menghambakan diri kepada Allah SWT. Pendidikan juga sebagai suatu kegiatan yang bersifat sosial kemasyarakatan yang sangat berpengaruh pada perkembangan masyarakat dan pada saatnya hasil dari pendidikan (lulusan pendidikan) akan terjun juga ke masyarakat untuk ikut serta mengembangkan masyarakat ${ }^{2}$. Maka dari itu masyarakat sangat membutuhkan lulusan yang kompeten dan berkarakter baik di era digital ini, karenanya rancangan suatu konsep pendidikan harus mempertimbangkan perkembagan masyarakat serta konsep tentang masyarakat yang ideal. Integritas antara pendidikan agama dan pendidikan karakter di dalam lembaga pendidikan kita merupakan sebuah keharusan jika kita ingin tetap setia pada pancasila ${ }^{3}$. Anak merupakan cikal bakal pemegang tampuk keberhasilan dunia di masa yang akan datang, anak-anak menjadi harapan majunya sebuah negara.

\footnotetext{
${ }^{1}$ Abuddin Nata, “Pendidikan Dalam Perspektif Al-Qur'an,” Jakarta: UIN Jakarta, 2005.

${ }^{2}$ Nata.

${ }^{3}$ Doni Koesoema, Pendidikan Karakter: Strategi Mendidik Anak Di Zaman Global, Jakarta: Grasindo, 2007.
} 
Anak dipersiapkan sedemikian rupa untuk memenuhi hal tersebut melalui pendidikan baik pendidikan formal ataupun non formal, baik pendidikan disekolah, di keluarga, maupun di masyarakat, juga pendidikan akademis, agama maupun moral, menjadi satu-satunya cara mempersiapkan generasi penerus bangsa yang akan memajukan peradapan sebuah negara. Berbicara tentang tujuan pendidikan Islam maka sangat berkaitan dengan karakter, karena karakter dianggap sebagai nilai-nilai perilaku manusia yang berhubungan dengan Tuhan yang maha Esa, diri sendiri, sesama manusia, lingkungan, dan kebnagsaan yang terwujud dalam pikiran, perasaan, dan perbuatan berdasarkan norma-norma agama, hukum, tata krama, budaya, adat istiadat dan etika ${ }^{4}$.

Sebenarnya tujuan pendidikan yang terdapat di dalam sistem pendidikan nasional kita sudah sangat lengkap untuk membentuk anak didik menjadi pribadi yang berlandaskan pada budi pekerti yang luhur. Namun seperti yang kita saksikan saat ini, para anak didik Indonesia seakan-akan sudah mengalami krisis budi pekerti. Bahkan berita tentang kriminal, bocah-bocah nakal, seakan-akan sudah menjadi santapan sehari-hari. Untuk itu, akan lebih baik bila sekolah juga menerapkan pendidikan karakter pada murid-murid didiknya. Pendidikan karakter ini merupakan penanaman nilai-nilai karakter kepada warga sekolah yang meliputi komponen pengetahuan, kesadaran, tindakan untuk melaksanakan nilai-nilai tersebut, baik terhadap tuhan, diri sendiri sesama, lingkungan maupun kebangsaan. Seseorang akan dikatakan berkarakter baik jika telah berhasil menyerap nilai dan keyakinan yang dikehendaki masyarakat serta digunakan sebagai kekuatan moral dalam hidupnya. ${ }^{5}$

Tujuan pendidikan karakter yaitu bertujuan untuk meningkatkan mutu proses dan hasil pendidikan yang mengarah pada pembentukan karakter dan akhlak mulia peserta didik secara utuh, terpadu, dan seimbang, dan standar sesuai dengan standar lulusan pada setiap satuan pendidikan ${ }^{6}$.

Ahmad D. Marimba mengemukakan bahwa Pendidikan Islam adalah bimbingan atau pimpinan secara sadar oleh pendidik terhadap perkembangan jasmani dan rohani peserta didik menuju terbentuknya kepribadian yang utama (insan kamil) ${ }^{7}$.

Menurut Zakiyah Darajat dalam bukunya karangan abdul Majid Pendidikan Agama Islam adalah suatu usaha untuk membina dan mengasuh peserta didik agar senantiasa dapat memahami ajaran Islam secara menyeluruh. Lalu menghayati tujuan, yang pada akhirnya dapat mengamalkan serta menjadikan Islam sebagai pandangan hidup ${ }^{8}$.

Menurut Ahmad Tafsir dalam bukunya Abdul Majid Pendidikan agama Islam adalah bimbingan yang diberikan seseorang kepada seseorang agar ia berkembang secara maksimal sesuai dengan ajaran Islam. Menurut Dr. H. Zuhairini Pendidikan

\footnotetext{
${ }^{4}$ Muchlas Samani, “Konsep Dan Model Pendidikan Karakter," n.d.

5 Rindufidati, isu-isu Pendidikan, https://rindufidati.wordpress.com/2015/09/25/isu-isu-pendidikan/, 25 September 2015, 2018

${ }^{6}$ H E Mulyasa, “Manajemen Pendidikan Karakter, Cet," V, Jakarta: Bumi Akara, 2013, 165.

${ }^{7}$ Samsul Nizar, Filsafat Pendidikan Islam: Pendekatan Historis, Teoritis Dan Praktis (Ciputat Pers, 2002).

${ }^{8}$ Abdul Majid and Dian Andayani, "Pendidikan Agama Islam Berbasis Kompetensi, Bandung: PT," Remaja Rosda Karya, 2005.
} 
Agama berarti usaha-usaha secara sistematis dan pragmatis dalam membantu anak didik agar supaya mereka hidup sesuai dengan ajaran Islam.

Dalam konteks ini, pendidikan karakter yang diharapkan dalam lembaga pendidikan bisa menjadikan salah satu sarana pembudayaan dan pemanusiaan. Karenanya kita inginkan dapat menciptakan sebuah lingkungan hidup yang menghargai hidup manusia, menghargai keutuhan dan keunikan ciptaan sehingga menghasilkan sosok pribadi yang memiliki kemampuan intelektual dan moral yang seimbang ${ }^{9}$. Pendidikan Islam sendiri sejatinya merupakan pendidikan yang terdiri dari pendidikan, pembelajaran dan pengajaran tentang segala aspek keIslaman yang wajib diketahui oleh setiap umatnya. Jadi pendidikan Islam wajib diberikan kepada umat Islam. Selain itu juga diberikan kepada mereka yang ingin mempelajari pendidikan Islam ${ }^{10}$.

Pendidikan di era digital ini sangatlah berkembang pesat, kemajuan teknologi saat ini tidak hanya dinikmati orang dewasa saja melainkan anak-anak umuran sekolah juga sudah sangat antusias dalam menikmati perkembangan teknologi di era digital sekarang ini, bahkan saat ini banyak anak-anak yang kecanduan gadget karenanya anak-anak kurang bersosialisasi dengan lingkungannya karena sibuk dengan gadgetnya masing-masing, dengan keadaan seperti ini tentu ada dampak positif dan negatif yang ditimbulkan. Dampak negatif yang sangat berbahaya di era digital ini salah satunya anak-anak akan kecantuan game, kurangnya bersosialisasi dikarenakan asik dengan ganget yang ia milikiakan tetapi dampak positifnya di era digital ini bahwa dengan adanya kemajuan teknologi aktifitas belajar siswa dimudahkan dengan adanya internet dan siswa dapat lebih mudah mencari ilmu pengetahuan secara cepat. Teknologi sebenarnya bermanfaat sangat besar bagi dunia pendidikan. Pencarian literasi-literasi untuk penambahan ilmu pengetahuan dalam pembelajaran, bisa memanfaatkan teknologi. Peserta didik dapat menelusuri internet untuk mempermudah dan mempercepat mendapatkan ilmu pengetahuan baru akan tetapi hal ini harus didampingi oleh pendidik atau orang tua agar tidak terjadi hal-hal yang menyeleweng dalam penggunaan internet ini ${ }^{11}$.

Pendidikan, tidak terlepas dengan seorang guru maka sebagai tenaga kependidikan, guru tidak hanya berperan sebagai penyampai materi pelajaran kepada peserta didik akan tetapi guru juga berperan sebagai pendidik, serta harus memposisikan diri secara aktif dan menempatkan kedudukannya sebagai tenaga professional. Guru profesional adalah guru yang memiliki kopetensi tertentu sesuai dengan persyaratan yang dituntut oleh profesi keguruan ${ }^{12}$. Guru bisa membangkitkan potensi anak didiknya untuk menempuh kesuksesan dengan mengembangkan rasa simpati dan empati pada sesamas. Tugas guru dan peran guru

\footnotetext{
${ }^{9}$ Koesoema, Pendidikan Karakter: Strategi Mendidik Anak Di Zaman Global.

${ }^{10}$ Implementasi Nilai-Nilai and Ali Miftakhu Rosyad, "Ali Miftakhu Rosyad IMPLEMENTASI NILAI-NILAI MULTIKULTURALISME MELALUI PEMBELAJARAN PENDIDIKAN AGAMA ISLAM THE IMPLEMENTATION OF MULTICULTURALISM VALUES THROUGH LEARNING OF ISLAMIC RELIGION EDUCATION" 5, no. 1 (2019), https://doi.org/10.5281/zenodo.2607388.

${ }^{11}$ Dini Palupi Putri, "Pendidikan Karakter Pada Anak Sekolah Dasar Di Era Digital," AR-RIAYAH : Jurnal Pendidikan Dasar, 2018, https://doi.org/10.29240/jpd.v2i1.439.

${ }^{12}$ Sudarwan Danim, Media Komunikasi Pendidikan: Pelayanan Profesional Pembelajaran Dan Mutu Hasil Belajar (Proses Belajar Mengajar Di Perguruan Tinggi) (Bumi Aksara, 2008).
} 
dari hari kehari semakin berat ${ }^{13}$, seiring dengan perkembangan ilmu pengetahuan dan teknologi, maka guru sebagai komponen utama dalam dunia pendidikan dituntut untuk mampu mengimbangi bahkan melampaui perkembangan ilmu pengetahuan dan teknologi yang berkembang dalam masyarakat ${ }^{14}$.

Pendidikan Islam tidak terlepas dengan pendidikan karakter yaitu bertujuan atau mengutamakan pertumbuhan moral individu yang ada dalam lembaga pendidikan ${ }^{15}$. Berbagai pandangan Al-Qur'an terhadap akhlak dan karakter yang demikian itu menjadi dasar yang penting bagi perumusan konsep pendidikan Islam, yaitu selain menjadi salah satu mata pelajaran, juga dapat dipertimbangkan dengan cara-cara membina akhlak yang merupakan jiwa dalam pendidikan Islam ${ }^{16}$. Berikut salah satu ayat Al-Qur'an yang berbicara tentang akhlak:

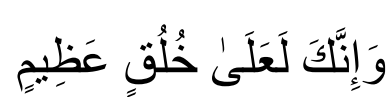

"Dan sesungguhnya kamu benar-benar berbudi pekerti yang agung (QS AlQalam: 4)"

Dari ayat di atas Imam Al-Maraghi ketika menafsirkan ayat tersebut mengatakan bahwa Allah telah memberkahi Nabi Muhammad SAW dengan sifat pemalu, memuliakan orang, pemberani, pemaaf, dan setiap akhak mulia lainnya ${ }^{17}$. Maka dari itu diharapkan manusia dididik agar bisa meniru akhlak Rasulullah SAW.

Mengingat proses pendidikan adalah suatu proses pengembangan kemampuan atau bakat manusia dengan sendirinya proses tersebut akan berjalan sesuai dengan hukum-hukum perkembangan, yaitu hukum organis, yang menyatakan bahwa perkembangan manusia berjalan secara menyeluruh dalam seluruh organ-organnya, baik organ tubuhnya maupun organ rohaniyahnya, oleh karena itu dalam perkembangan jiwa manusia sangatlah memerlukan bimbingan, arahan, dan pendidikan yang dapat membina jiwa yang optimal serta nilai-nilai yang dijadikan sebagai suatu pegangan hidupnya terlebih di era digital sekarang banyak dihaerapkan dari alat-alat teknologi membantu mengatasi berbagai masalah pendidikan misal untuk mengatasi kekurangan guru guna memenuhi aspirasi belajar $^{18}$. Dengan demikian, perlu adanya sesuatu yang menunjang akan perkembangan jiwa manusia sehingga diharapkan menjadi manusia yang tidak cuma berkualitas di hadapan masyarakat tetapi di hadapan Allah Swt. ${ }^{19}$

Alasan peneliti memilih salah satu buku dari Abuddin Nata dengan judul Pendidikan dalam Perspektif Al-Qur'an karena beliau salah satu pakar pendidikan

\footnotetext{
${ }^{13}$ Ali Miftakhu Rosyad, "Al-Afkar, Journal for Islamic Studies URGENSI INOVASI PEMBELAJARAN DALAM PENDIDIKAN AGAMA ISLAM Al-Afkar, Journal for Islamic Studies THE URGENCY OF LEARNING INNOVATION ON ISLAMIC RELIGIOUS STUDY" 3, no. 1 (2019), https://doi.org/10.5281/zenodo. 2546882.

${ }^{14}$ E Kunandar and M Si, “Guru Profesional," Jakarta: Rajawali Pers, 2014.

${ }^{15}$ Koesoema, Pendidikan Karakter: Strategi Mendidik Anak Di Zaman Global.

${ }^{16}$ Nata, "Pendidikan Dalam Perspektif Al-Qur'an."

${ }^{17}$ Nata.

${ }^{18}$ S Nasution, Teknologi Pendidikan (Bumi Aksara, 1994).

Sidik Nuryusupiandi, proposal penelitian nilai-nilaipendidikan Islam bagi remaja, https://senyumsederhanaku.blogspot.com/2016/11/proposal-penelitian-nilai-nilai.html, 2016: 15 Desember 2018
} 
Islam, buku ini sangat menarik untuk diteliti karena berkaitan dengan judul skripsi ini, dan sangat membantu peneliti yang sedang bergelut dalam bidang pendidikan Islam maka buku ini penting untuk semakin memahami bagaimana pendidikan Islam itu sendiri yang sesuai dengan landasan Al-Qur'an berbicara tentang pendidikan baik ilmu pendidikan Islam maupun pendidikan pada umumnya selalu dijumpai pembahasan tentang seorang guru maka dalam buku ini ada pembahasan juga mengenai guru yang kebetulan saya sedang bergelut dalam bidang pendidikan Islam atau keguruan, salah satu kelebihan dari buku ini sangat berkaitan dengan AlQur'an yang memuat konsep dan pandangan Islam tentang pendidikan, pembahasannya mudah untuk di pahami, uraiannya menambah keyakinan dan kecintaan umat terhadap Al-Qur'an sebagai pedoman hidup yang bukan saja berisi informasi tentang kehidupan akhirat dan masalah-masalah ibadah, melaikan berisi pula petunjuk tentang prinsip-prinsip dalam konsep pendidikan. Tujuan dari penelitian ini untuk menambah pengetahuan bahwa tujuan pendidikan Islam di era digital sekarang ini sangat penting mengingat banyaknya pengaruh negativ yang bisa merusak moral bangsa. Untuk itu kita sebagai generasi muda tidak boleh menutup mata akan hal ini, dimulai dari diri sendirilah kita menanamjan nilai-nilai agama Islam dalam kehidupan sehari-hari. Maka dari itu kita harus tetap semangat dalam menyebarkan tujuan pendidikan Islam. Penelitian ini berdampak sangat positif untuk pendidikan di Indonesia karena dengan memahami tujuan pendidikan Islam dengan benar maka akan tertanamkan jasmani dan rohani berdasarkan hukumhukum agama Islam menuju terbentuknya sikap menurut kaidah-kaidah Islam.

Pendidikan karakter di Indonesia pertamakali dicetuskan oleh Ratna Megawangi, alumnus IPB yang peduli terhadap dunia pendidikan khususnya pendidikan anak dan perempuan. Ratna Megawangi mendapatkan pilar karakter yang akan dibangun, yaitu "cinta Tuhan dan segenap ciptaanNya, kemandirian dan tanggung jawab, kejujuran diplomatis, hormat dan santu, dermawan, tolong menolong, percaya diri, kepemimpinan" ${ }^{20}$. Istilah karakter dihubungkan dan dipertukarkan dengan istilah etika, ahlak, dan atau nilai dan berkaitan dengan kekuatan moral, berkonotasi "positif" bukan netral. Oleh karena itu Pendidikan karakter secara lebih luas dapat diartikan sebagai pendidikan yang mengembangkan nilai budaya dan karakter bangsa pada diri peserta didik sehingga mereka memiliki nilai dan karakter sebagai karakter dirinya, menerapkan nilai-nilai tersebut dalam kehidupan dirinya sebagai anggota masyarakat, dan warga negara yang religius, nasionalis, produktif, dan kreatif. ${ }^{21}$

Karakter adalah suatu tindakan yang dilakukan secara sepontan tanpa melalui proses perfikir, karakter sama halnya dengan akhlak yang merupakan komponen dasar Islam yang berisi ajaran tentang perilaku, atau sopan santau, atau dengan kata lain dapat disebut sebagai aspek ajaran Islam yang mengatur perilaku manusia. ${ }^{22}$

\footnotetext{
${ }^{20}$ Ratna Megawangi, “Pendidikan Karakter (Solusi Yang Tepat Untuk Membangun Bangsa),” Jakarta: Indonesia Herritage Foundation, 2004.

${ }^{21}$ Nur Aniyah, "Pembentukan Karakter Melalui Pendidikan Agama Islam”, Jurnal Al-Ulum (Jurnal StudiStudi Islam) IAIN Gorontalo, Volume. 13 Nomor 1, 2013, hal. 27

${ }^{22}$ Prof. Dr. Azyumardi Azra, Drs. Toto Suryana, M.Pd., Prof. Dr. H. Ishak Abdulhaq, M.Pd., Dr. H. Didin Hafiduddin., Pendidikan Agama Islam pada Perguruan Tinggi Umum, ( Departemen Agama RI: 2002), 108
} 
Dalam istilah psikologi, yang disebut karakter adalah watak perangai sifat dasar yang khas satu sifat atau kualitas yang tetap terus menerus dan kekal yang dapat dijadikan ciri untuk mengidentifikasi seorang pribadi. Berbicara tentang karakter sangat erat kaitannya dengan pendidikan maka dari itu pendidikan karakter merupakan bagian dari kinerja sebuah lembaga pendidikan yang di dalamnya terdapat berbagai macam keterlibatan individu dan tata aturan kelembagaan ${ }^{23}$. Oleh karena itu, pendidikan karakter di sekolah dapat di pahami melalui dua cara yaitu cara pertama memandang pendidikan karakter dalam cangkupan pemahaman moral yang lebih sempit. Yang kedua melihat pendidikan karakter dari sudut pandang pemahaman isu-isu yang lebih luas ${ }^{24}$

Pendidikan karakter sebagai sebuah pedagogi memiliki tujuan agar setiap pribadi semakin menghayati individualitasnya, mampu menggapai kebebasan yang dimilikinya sehingga ia dapat semakin berumbuh sebagai pribadi maupun sebagai warga negara yang bebas dan bertanggung jawab, bahkan sampai tingkat bertanggung jawab moral integral atau kebersamaan hidup dengan yang lain di dalam dunia. Pendidikan karakter sebagai pedagogi merupakan satu keping dari dua sisi paradigma pendekatan moral dalam pendidikan yaitu pendekatan moral dalam lingkup yang lebih sempit yaitu, dalam sekolah, dan dalam lingkup lebih luas, yaitu dalam relasi individu dengan lembaga lain, berupa peristiwa-peristiwa dalam dunia pendidikan. $^{25}$

Banyak para cendekiawan muslim baik yang klasik, maupun modern yang memberikan jerih payahnya dan mendedikasikan diri dalam meletakkan fondasi dasar tujuan pendidikan Islam, salah satunya adalah Prof. Dr. H. Abuddin Nata M.A. Dalam karyanya yang buku berjudul Pendidikan dalam Perspektif AlQur'an penulis menemukan konsep tujuan pendidikan Islam sehingga dapat memberikan pencerahan untuk membangun karakter siswa di era digital.

\section{Metode Penelitian}

Metodelogi penelitian yaitu merupakan cara ilmiah untuk mendapatkan suatu data dengan tujuan dan kegunaan tertentu pada metodelogi penelitian ini maka penulis akan membahas mengenai :

1. Paradigma atau Pendekatan Penelitian

Penelitian ini merupakan penelitian dengan pendekatan kepustakaan (library research) yang merupakan bagian pendekatan dari metode kualitatif yaitu penelitian yang berdasarkan pada buku, jurnal, makalah, web (internet), majalah maupun laporan penelitian terdahulu atupun terdapat informasi dari surat-surat keterangan lainnya dan sebagainya. ${ }^{26}$

\footnotetext{
${ }^{23}$ Ali Miftakhu Rosyad et al., "SMP N2 Juntinyuat 2 Universitas Negeri Yogyakarta THE ACTUALIZATION OF CHARACTER EDUCATION BASED ON SCHOOL CULTURE IN SOCIAL STUDIES LEARNING IN JUNIOR HIGH SCHOOL," Harmoni Sosial: Jurnal Pendidikan IPS 5, no. 1 (2018): 79-92, http://journal.uny.ac.id/index.php/hsjpi.

${ }^{24}$ Doni Koesoema, Pendidikan Karakter, (jakarta: Pt Grasindo, 2017), 125.

${ }^{25}$ Doni Koesoema, Pendidikan Karakter, 153

${ }^{26}$ Ade Ayu Fatimah, S.Pd., "Konsep Pendidikan Islam dalam Pembangunan Sumber Daya Manusia di Era Globalosasi”, Proposal Skripsi, (Indramayu: Rumah Peneliti, 2018), 15, t.d.
} 
Maka dengan demikian, penulis akan dapat mendeskripsikan serta mampu membuat sebuah narasi yang panjang sesuai dengan acuan-acuan dalam penulisan. Penulisan menggunakan penelitian kualitatif deskriptif yang bersifat kepustakaan yg berkaitan dengan konsep Prof. Dr. H. Abuddin Nata, M.A tentang Tujuan Pendidikan Islam Guna Membangun Karakter Siswa di Era Digital.

2. Metode penelitian

Metode Penelitian merupakan suatu cara untuk memecahkan suatu masalah atau cara untuk mrngembangkan ilmu pengetahuan dengan menggunakan metode ilmiah untuk mendapatkan suatu data yang valid, dengan tujuan anatara lain dapat dikembangkan dan di buktikan, suatu pengetahuan tertentu sehingga pada suatu saat nanti dapat digunakan untuk memahami, memecahkan dan mengantisipasi masalah. ${ }^{27}$

Penelitian ini menggunakan metode kualitatif yang sering digunakan untuk melihat fenomena sosial termasuk didalamnya kajian terhadap ilmu pendidikan, manajemen, ilmu hukum dan lain-lain. Pada dasarnya penelitian kualitatif diajukan untuk penelitian mengamati kasus, demikian proses kasus pengumpulan data dan analisis data bersifat kasus pula. ${ }^{28}$ Karena penelitian ini menggunakan metode kualitatif maka akan memecahan masalah secara rasional yang terarah serta mendalam dengan cara mencari data yang berkaitan dengan kajian tentang tujuan pendidikan Islam guna membangun karakter siswa di era digital pemikiran Prof. Dr. H. Abuddin Nata, M.A.

3. Teknik Penelitian

Dalam teknik pengumpulan data peneliti membagi beberapa teknik:

a. Teknik Pengumpulan Data

Teknik pengumpulan data ini melalui studi observasi dan dokumentasi diartikan sebagai upaya untuk memperoleh data berupa catatan tertulis yang tersimpan berkaitan dengan masalah yang diteliti. Teknik penggumpulan data ini bersumber dari beberapa dokumentasi yang berasal dari buku, internet jurnal dan karya ilmiah lainnya. Di bawah ini akan di uraikan teknik penelitian sebagai cara yang dapat ditempuh untuk mengumpulkan data.

1) Teknik Observasi

Teknik observasi diartikan sebagai pengamatan secara sistematik terhadap gejala yang tampak pada objek penelitian. Pengamatan dan pencatatan yang dilakukan terhadap objek di tempat terjadi atau berlangsungnya peristiwa, sehingga observasi berada bersama objek yang diselidiki, disebut observasi langsung. Sedangkan observasi tidak langsung adalah pengamatan yang dilakukan tidak pada saat berlangsungnya peristiwa, misalnya peristiwa tersebut diamati melalui film, ragkaian slide, atau rangkaian poto. ${ }^{29}$

\footnotetext{
${ }^{27}$ Ade Ayu Fatimah, S.Pd., "Konsep Pendidikan Islam dalam Pembangunan Sumber Daya Manusia di Era Globalosasi”, Proposal Skripsi, 16, t.d.

${ }^{28}$ Prof. Dr. Rully Indrawan, M.Si., Prof. Dr. R. Poppy Yaniawati, M.Pd., Metodologi penelitian, (Bandung: PT Refika Aditama, 2017), 67

${ }^{29}$ Margono, Metodologi Penelitian Pendidikan, (Jakarta: Rineka Cipta, 2010), 181
} 


\section{2) Teknik Dokumentasi}

Teknik dokumentasi adalah cara mengumpulkan data melalui peninggalan tertulis seperti arsip-arsip dan termasuk juga buku-buku tentang pendapat, teori, dalil, atau hukum-hukum dan lain-lain yang berhubungan dengan masalah penelitian tersebut. Dalam penelitian kualitatif teknik ini merupakan alat pengumpulan data yang utama karena pembuktian hipotesisnya yang diajukan secara logis dan rasional melalui pendapat, teori atau hukum-hukum yang diterima, baik mendukung maupun yang menolong hipotesis tersebut. ${ }^{30}$

\section{b. Teknik Analisis Data}

Teknik analisis data adalah proses mencari dan menyusun secara sistematis data yang diperoleh. ${ }^{31}$ Penelitian menggunakan analisis data kualitatif yang bersifat deduktif, yaitu suatu analisis berdasarkan data yang diperoleh, selanjutnya dikhususkan dengan pola hubungan tertentu. ${ }^{32}$ Dalam penelitian ini dapat diperoleh dari berbagai sumber kemudian dikumpulkan yang akan dijadikan sumber dalam penelitian.dari data-data yang didapat peneliti menganalisis sebagai berikut:

1) Menganalisis tujuan pendidikan Islam

2) Menganalisis tujuan pendidikan Islam dalam membangun karakter siswa di era digital

3) Imenentukan inventarisasi judul-judul pustaka yang berhubungan dengan masalah penelitian

4) Melakukan pemilihan isi dalam bahan pustaka, hal ini dapat dilakukan dengan cara pemilihan topik daftar isi atau sub judul dalam masing-masing judul

5) Melakukan penelaahan terhadap isi tulisan dalam pustaka yang berkaitan dengan penelitian ini

\section{HASIL DAN PEMBAHASAN}

\section{Biografi Prof. Dr. H. Abuddin Nata M.A}

Prof. Dr. H. Abuddin Nata, M.A lahir pada tanggal 2 Agustus 1954 lahir di Desa Cibuntu Kulon, Kecamatan Ciampea Kabupaten Bogor, Jawa Barat. Abuddin Nata dari kecil di sekolahnya sebagai siswa yang aktif semasa di madrasah aktif sebagai ketua kelas, dan semasa di PGA tsanawiyah, dan PGAA aktif sebagai ketua kesiswaan, olahraga, seni, pengembangan minat bakat dan lainnya dengan meraih berbagai prestasi dan kejuaraan, adapun semasa menjadi mahasiswa di intra aktif sebagai pengurus senat Mahasiswa Fakultas Ilmu Tarbiyah dan Keguruan, serta Ketua Badan Koordinasi Kegiatan Mahasiswa (BKK) yang setingkat dengan dewan mahasiswa, adapun di ektra aktif di Himpunan Mahasiswa Islam (HMI), dimulai sebagai ketua HMI komisariat Fakultas Ilmu Tarbiyah dan Keguruan, Ketua Lembaga Pendidikan Mahasiswa Islam (Lapenmi), hingga menjadi sebagai ketua II Himpunan Mahasiswa Islam Cabang Ciputat. Kegiata di HMI ini dimulai sejak tahun

\footnotetext{
${ }^{30}$ Maman Rachman, Strategi Dan Langkah-Langkah Penelitian Pendidikan, (semarang: semarang pres, 1993), 90

${ }^{31}$ Sugiyono, Metode Penelitian Kuantitatif, Kualitatif, $R \& D$, (Bandung: Alfabeta, 2012), 9

${ }^{32}$ Sugiyono, Metode Penelitian Pendidikan, (Bandung: Alfebeta, 2013) 335
} 
1975, hingga sekarang dengan jabatan sebagai ketua presidium korp HMI (Kahmi) Cabang Ciputat. ${ }^{33}$

Bersamaan dengan melaksanakan tugas pokok sebagai dosen, juga ia dipercaya menduduki berbagai jabatan antara lain sebagai sekertaris balai praktikum, sekertaris Jurusan Kependidikan Islam dan Pembantu DekanFakultas Ilmu Pendidikan dan Keguruan UIN Syarif Hidayatullah Jakarta. Setelah itu dipercaya sebagai pembantu rektor Bidang Administrasi Umum (Purek II) semasa Profesor Azyumardi Azra sebagai Rektor dari tahun 1997 sampai 2006. Pada masa menduduki jabatan sebagai Pembantu Rektor Bidang Administrasi ini, terjadi perubahan IAIN menjadi UIN, pengembangan kelembagaan, pembangunan infrastruktur, penguatan sumber daya manusia, perluasan bidang kerjasama, pembenahan manajemen, pembinaan lingkungan akademik, dan lain sebagainya. ${ }^{34}$

Ayahnya bernama (alm.) Muallim Nata, tamatan pesantren Balai Rombeng Salafiyah di Banten, ia bekerja sebagai guru ngaji, imam dan khatib di Masjid kampung, sambil berdagang dan bertani menggarap sawah milik tetangganya. Adapun ibunya bernama (alm.) Siti Aisyah, ia seorang wanita tak pandai baca tulis, namun ibu Siti Aisyah taat beragama, patuh pada suami, bekerja sebagai ibu rumah tangga dan membantu pekerjaan suami di sawah. ${ }^{35}$

Beberapa negara yang telah dikunjungi antara lain Saudi Arabia, Mesir, Iran, Turki, Filipina, Thailan, Singapura, Hongkong, Malaysia, Belanda, Perancis, Swiss, Belgia, Itali, Roma, Patikan, Kanada, Jepang, Australia, Amerika Serikat. Sekarang tinggal di jalan Akasia Nomor 54 Rt 002/o12 Pamulang Timur Tangerang Selatan Banten, dengan istri Elisah Angriani, seorang ibu rumah tangga, aktivitas Dharma Wanita UIN Syarif Hidayatullah dan pengusaha. Anak pertama Elta Diyarsyah, tamatan ITB jurusan Teknik Fisika, sudah menikah dan bekerja sebagai pengusaha, anak kedua Bunga Yustisia, tamatan Universitas Bina Nusantara, juusan Teknik Komputer, sudah menikah sebagai ibu rumah tangga dan pengusaha.

Pendidiikannya dimulai dengan belajar di Madrasah Ibtidaiyah di Jati Pinggir, Tanah Abang Jakarta Pusat sampai dengan kelas III, dan kemudian dilanjutkan di Madrasah Ibtidaiyah Wajib Belajar di Desa Nagor Ciampea Bogor, hingga tamat tahun 1968. Selanjutnya setelah tamat Pendidikan Guru Agama (PGA) 4 tahun di Nagor Ciampea Bogor sambil ngaji kitab kuning di pondok pesantren Nurul Ummah dan belajar di madrasah tsanawiyah ( di sore hari) di alamat yang sama, pada tahun 1972. Pendidikannya dilanjutkan di pendidikan guru agama tingkat atas (PGAA/PG 6 $\mathrm{TH}$ ), sambil mondok ngaji kitab di pondok pesantren Jauharatun Naqiyah, Cibeber, Cilegon Banten, hingga tamat tahun 1974. selanjutnya pada tahun 1978 merain gelar sarjana muda (BA) Jurusan Pendidikan Agama Islam dengan judul Risalah Taqwa sebagai Tujuan Pendidikan, dan pada tahun 1982 meraih gelar sarjana lengkap (Drs.) jurusan Pendidikan Agama pada Fakultas Ilmu Tarbiyah dan Keguruan UIN Syarif Hidayatullah Jakarta. Pada tahun 1994 meraih gelar Magister (M.A.) jurusan Pendidikan Agama Islam tanpa tesis dengan nilai rata-rata A dan pada tahun 1997

\footnotetext{
${ }^{33}$ Prof. Dr. H. Abuddin Nata, M.A., Penndidikan dalam Perspektif Al-Qur'an, (Depok: Prenadamedia Group, 2016), 308

${ }^{34}$ Prof. Dr. H. Abuddin Nata, M.A., Penndidikan dalam Perspektif Al-Qur'an, 309

${ }^{35}$ Prof. Dr. H. Abuddin Nata, M.A., Penndidikan dalam Perspektif Al-Qur'an, 307
} 
meraih gelar Doktor pendidikan Agama Islam selanjutnya pada tahun 1999-2000 mengikuti post Doktorat Program pada Islamis Studies, McGill University, Montreal, Canada, lalu pada tahun 2004 meraih gelar Profesor Bidang Pendidikan Islam, dengan judul pidato pengukuhan: tantangan dan peluang pendidikan Islam di Indonesia. ${ }^{36}$

Prof. Dr. H. Abuddin Nata, M.A. ditengah-tengah kesibukannya beliau juga mempunyai banyak karya tulis berupa buku dalam bidang agama dan pendidikan Islam dalam jumblam mencapai 50 judul, beberapa diantaranya yaitu: Sejarah Agama, Ilmu Tauhid, Dirasat Islamiyah, Metodologi Studi Islam, Studi Islam Komperhensif, Pendidikan salam Prespektif Al-Qur'an, Kapita Selekta Pendidikan Islam, Filsafat Pendidikan Islam, Sejarah Pendidikan Islam, Sejarah Sosial Intelektual Pendidikan Islam, Sosiologi Pendidikan Islam, Paradigma Pendidikan Islam, Pendidikan Islam di Era Global, Ilmu Pendidikan Islam, Manajemen Pendidikan Islam, sejarah pertumbuhan dan perkembangan, sejaran pertumbuhan dan perkembangan lembaga-lembaga pendidikan Islam, pendidikan Islam multidisipliner, akhlak tasawuf, Islamisasi ilmu pengetahuan, pemikiran para tokoh pendidikan Islam, ilmu kalam, filsafat dan tasawuf, peta keragaman pendidikan Islam di indonesia, tema-tema pokok al-qur'an bibliografi beranotasi al-qur'an, materi dakwah terurai, menuju guru uang profrsional, pendidikan dalam prespektif hadis, kontributor tulisan untuk ensiklopedia Islam, Ensiiklopedia Islam di Indonesia, modul program penyetaraan guru agama Islam, Perspektif Islam Tentang Pendidikan Kedokteran, Strategi Pembelajaran, Fikih Kedokteran, Pembaruan Pendidikan Islam, dan lain sebagainya.

\section{Pemikiran Prof. Dr. H. Abuddin Nata M.A}

Pendidkkan adalah suatu kegiatan yang bersifat sosial kemasyarakatan sangat dipengaruhi oleh perkembangan masyarakat, dan pada gilirannya hasil pendidikan (lulusan pendidikan) akan terjun kemasyarakat untuk ikut serta membantu dan mengembangkan masyarakat. ${ }^{37}$ Atas dasar ini suatu konsep pendidikan harus mempertimbangkan perkembangan masyarakat serta konsep tentang masyrakat yang ideal.

Pendidikan merupakan, proses perubahan atau pendewasaan manusia, berawal dari tidak tahu menjadi tahu, dari tidak biasa menjadi biasa, dari tidak paham menjadi paham dan dari tidak trampil menjadi trampil dan kurang dan kurang berkarakter menjadi berkarakter (akhlak mulia). Sehingga, pendidikan bisa didapatkan dam dilakukan dimana saja, bisa di lingkungan sekolah, masyarakat dan keluarga, dan yang penting untuk diperhatikan adalah bagaimana memberikan atau mendapat pendidikan dengan baik dan benar agar manusia tidak terjerumus dalam kehidupan yang negatif. Pendidikan mempunyai peranan yang sangat penting dalam menjamin kelangsungan hidup negara, karena pendidikan merupakan sarana untuk

\footnotetext{
${ }^{36}$ Prof. Dr. H. Abuddin Nata, M.A., Penndidikan dalam Perspektif Al-Qur'an, (Depok: Prenadamedia Group, 2016), 308

${ }^{37}$ Prof. Dr. H. Abuddin Nata, M.A., Penndidikan dalam Perspektif Al-Qur'an, 50
} 
meningkatkan dan mengembangkan kualitas sumber daya manusia. Dengan pendidikan kehidupan manusia menjadi terarah.

Dasar pendidikan yaitu merupakan pandangan hidup yang melandasi seluruh aktivitas pendidikan. Karena dasar menyangkut masalah ideal dan fundamental, maka diperlukan landasan pandangan hidup yang kukuh dan komperhensif, serta tidak mudah berubah, karena diyakini memiliki kebenaran yang telah teruji oleh $\operatorname{sejarah}^{38}$. Selanjutnya karena pandangan hidup (telogi) seorang muslim berdasarkan Al-Qur'an dan al-Sunnah, maka yang menjadi dasar pendidikan Islam adalah Al-Qur'an dan al-Sunnah. Hal yang demikian dilakukan karena dalam teologi umat Islam, Al-Qur'an dan al-Sunnah diyakini mengandung kebenaran yang multak yang bersifat transendental, universal, dan eternal (abadi), sehingga secara akidah diyakini oleh pemeluknyaakan selalu sesuai dengan fitrah manusiaartinya memenuhi kebutuhan manusia kapan dan dimana saja.

Berdasarkan analisis terhadap potensi untuk beragama dan tidak beragama sebagaimana tersebut, maka kerangka tujuan pendidikan Islam itu dirumuskan, yaitu berupaya membina dan mengarahkan agar potensi untuk berbuat baik, beriman, dan tunduk kepada Allah yang selanjutnya disebut bertakwa itu dirumuskan. Melalui kegiatan pendidikan Islam yang demikian itu, maka manusia dibina dan dibiasakan hidupnya agar menjadi orang yang senantiasa mengikuti kecenderungan baiknya dan diupayakan pula agar manusia tersebut tidak mengikuti kecenderungan buruknya. ${ }^{39}$

Tujuan pendidikan Islam tidak keluar dari kerangka pengertian ini, yaitu mempersiapkan manusia untuk menghambakan diri kepada Allah SWT. Dengan demikian dapat dikatakan bahwa tujuan pendidikan Islam ialah mempersiapkan, mengembangkan, dan membangun manusia yang beribadah kepada Allah. Dikalangan para ahli pendidikan Islam, banyak dijumpai pendapat yang merumuskan bahwa tujuan pendidikan Islam membina manusia agar memiliki karakter yang baik ${ }^{40}$.

Karakter adalah perbuatan yang yang dilakukan dengan mudah dan tanpa pemikiran terlebih dahulu. Ini tidak berarti bahwa pada saat melakukan sesuatu perbuatan, yang bersangkutan dalam keadaan tidak sadar, hilang ingatan, tidur atau gila. Pada saat yang bersangkutan melakukan sesuatu perbuatan ia tetap sehat akal pemikiran dan sadar. Oleh karena itu perbuatan yang dilakukan oleh seseorang dalam keadaan tidur, hilang ingatan, mabuk, atau perbuatan refleksi seperti berkedip, tertawa dan sebagainya bukanlah perbuatan akhlah ataupun karakter. Perbuatan akhlak adalah perbuatan yang dilakukan oleh orang yang sehat akal pemikirannya. Namun karena perbuatan tersebut sudah mendarah daging maka pada saat akan mengerjakannya sudah tidak lagi memerlukan pertimbangan atau pemikiran lagi hal yang demikan tak ubahnya dengan seseorang yang sudah

\footnotetext{
${ }^{38}$ Nata, "Pendidikan Dalam Perspektif Al-Qur'an."

${ }^{39}$ Prof. Dr. H. Abuddin Nata, M.A., Penndidikan dalam Perspektif Al-Qur'an, 142

${ }^{40}$ Ibnu Rusydi, "Paradigma Pendidikan Agama Integratif-Transformatif," Jurnal Pendidikan Islam, 1970, https://doi.org/10.14421/jpi.2011.11.105-120.
} 
mendarah daging mengerjakan solat lima waktu, maka pada saat datang panggilan shalat ia tidk lagi merasa berat lagi mengerjakannya dan tanpa pikir-pikir lagi dan ia sudah dengan mudah dan ringan dalam mengerjakannya. ${ }^{41}$

Untuk mendapatakan karater yang baik atau akhlak yang mulia maka perseta didik harus dibina dengan benar dan pada kenyataannya dilapangan, usaha-usaha pembinaan akhalak melalui berbagai lembaga pendidikan dan melalui berbagai macam metode terus dikembangkan. Ini menujukan bahwa akhlak memang perlu dibina, dan pembinaan ini ternyata membawa hasil berupa terbentuknya pribadipribadi muslim yang berakhlak mulia, taat kepada Allah dan Rasulnya, hormat kepada ibu bapak, sayang kepada sesama mahluk tuhan dan seterusnya. Sebaliknya keadaan sebaliknya juga menunjukan bahwa anak-anak yang tidak dibina akhlaknya, atau dibiarkan tanpa bimbingan, arahan dan pendidikan, ternyata menjadi anakanak yang nakal, mengganggu masyrakat, melakukan berbagai perbuatan tercela dan seterusnya. Ini menunjukan bahwa akhlak memang perlu dibina. ${ }^{42}$

Pandangan baru terhadap akhlak di era digital ini pada tahap selanjutnya mampu mengubah konsep-konsep akhlak termasuk dalam menilai sesuatu yang baik dan mulia. Keutamaan kedermawanan misalnya tidak lagi dianggap mempunyai nilai yang tinggi sebagaimana yang terjadi pada abad pertengahan. Sementara masalah keadilan menempati posisi sebagai akhlak yang mulia yang melampaui pandangan abad sebelumnya. Selanjutnya pandangan akhlak mereka diarahkan pada perbaikan yang berkaitan dengan kehidupan para pemuda, wanita dan anak-anak dengan tujuan agar mereka menjadi anggota masyarakat yang mandiri. Penyelidikan baru yang mereka lakukan itu berjasa bagi penentuan patokan mengenai hak dan kewajiban yang pada akhirnya melahirkan masyarakat yang bersifat individualistik, mandiri dan inovatif. ${ }^{43}$

\section{Hasil Penelitian Tentaang Tujuan Pendidikan Islam dalam membangun Karakter Siswa di Era Digital}

1. Membangun Karakter Siswa

a. Memberi Arahan

Memberi arahan bukan hanya tuhas guru di sekolah melainkan orang tua juga sangat berperan bagaimana mengarahkan supaya putra putrinya memiliki karakter yang baik misalnya memberi arahan bahwa sampah itu harus dibuang pada tempatnya tidak boleh sembarangan.

b. Memberi Contoh

Mencuntohkan atau memperaktekannya supaya anak bisa melihat bahwa yang dilakukannya itu adalah salah satu contoh karakter yang baik.

c. Pembiasaan

\footnotetext{
${ }^{41}$ Prof. Dr. H. Abuddin Nata, M.A., Akhlak Tasawuf, (Jakarta: Raja Grafindo Persada, 2009), 5

${ }^{42}$ Prof. Dr. H. Abuddin Nata, M.A., Akhlak Tasawuf, 157

${ }^{43}$ Prof. Dr. H. Abuddin Nata, M.A., Akhlak Tasawuf, (Jakarta: Raja Grafindo Persada, 2009), 82
} 
Setelah mengarahkan dan mencontohkan tugas selanjutnya pembiasaan supaya perilaku tersebut menjadi salahsatu karakter yang melekat pada kepribadian siswa.

Selama ini pendidikan Islam selalu dipandang sebelah mata dan selalu terpojokan dikalangan sebagian masyarakat. Hal ini dibuktikan ketika ada kenakalan yang dilakukan oleh siswa-siwa, sebagian kalangan masyarakat menyalahkan pendidikan Islam karena dianggap tidak berberhasil dalam menjalankannya atau dianggap kurang maksimal dalam pengajarannya, maka dari itu menyikapi hal di atas pemerintah terus melakukan pembenahan-pembenahan yang bertujuan untuk dapat memaksimalkan tujuan dari pendidikan Islam dan sistem pendidikan Islam supaya tidak dipandang sebelah mata oleh semua pihak ${ }^{44}$.

Para ahli pendidikan Islam telah sepakat bahwa maksud dari pendidikan dan pengajaran bukanlah memenuhi otak anak didik dengan segala macam ilmu yang belum mereka ketahui, melainkan maksudnya ialah mendidik akhlak dan jiwa mereka, menanamkan rasa Fadhilah (keutamaan), membiasakan mereka dengan kesopanan yang tinggi, mempersiapkan mereka untuk suatu kehidupan yang suci seluruhnya, ikhlas, dan jujur. Dengan demikian maka, jujuan pokok dan terutama dalam pendidikan Islam yaitu mendidik budi pekerti dan pendidikan jiwa. Semua mata pelajaran haruslah mengandung pelajran-pelajaran akhlak, setiap guru haruslah memikirkan akhlak keagamaan sebelum yang lain-lainnya karena akhlak keagamaan adalah akhlak tertinggi, sedangkan akhlak yang muliah adalah tiang dari pendidikan Islam. ${ }^{45}$

Akhlak merupakan ajaran tentang perilaku dan sopan santun atau dengan kata lain akhlak dapat disebut sebagai aspek ajaran Islam yang mengatur perilaku manusia. Akhlak merupakan bagian yang sangat penting dalam ajaran Islam, karena perilaku manusia merupakan objek yang utama ajaran Islam. Bahkan maksud diturunkannya agama adalah untuk membimbing akhlak atau karakter manusia agar sesuai dengan fitrahnya. Agama menyuruh manusia agar meninggalkan kebiasaan buruk dan menggantikannya dengan sikap dan perilaku yang baik. Agama menuntun manusia agar memelihara dan mengembangkan kecenderungan mental yang bersih dan jiwa yang suci. Karena itu Rasulullah bersabda:

"tidaklah aku diutus untuk menyempurnakan akhlak dan perilaku manusia"

Alhasil, akhlak merupakan sistematika Islam. Sebagai sistem akhlak memiliki spektrum yang luas, mulai sikap terhadap dirinya, orang lain, serta terhadap Tuhannya. Maka dari itu tujuan dari pendidikan Islam yaitu berupaya membina dan mengarahkan agar peserta didik berbuat baik, beriman dan tunduk kepada Allah SWT dan juga membentuk karakter peserta didik agar memiliki akhlak dan budi pekerti yang baik. Maka dari itu untuk mewujudkan iu semua proses belajar juga sangat mempengaruhi dalam proses pembentukan karakter peserta didik karena proses belajar tidak hanya mentranformasikan pengetahuan, wawasan, pengalaman, dan keterampilan pada peserta didik, melainkan juga menggali, mengarahkan dan

\footnotetext{
${ }^{44}$ Rusydi, "Paradigma Pendidikan Agama Integratif-Transformatif."

${ }^{45}$ Prof. Dr. H. Abuddin Nata, M.A., Penndidikan dalam Perspektif Al-Qur'an, (Depok: Prenadamedia Group, 2016), 149
} 
membina seluruh potensi yang ada dalam diri peserta didik sesuai dengan tujuan yang direncanakan. Mengingat bahwa pengembangan karakter adalah proses terus menerus, karakter bukanlah kenyataan, melainkan keutuhan perilaku. Karakter bukanlah hasil atau produk, melainkan usaha hidup usaha ini akan semakin efektif ketika manusia melaksanakan apa yang memang masih mungkin bisa dilakukan oleh manusia. Manusia berbeda dengan binatang karenanya ia memiliki kemungkinankemungkinan yang terbuka dimasa depan manusia mampu memodifikasi hidupnya dan membuat sebuah proyek bagi masa depannya.

Pendapat seperti ini juga dijumpai pada pendapat Ki Hajar Dewantara yang mengatakan, bahwa pendidikan pada umumnya berarti daya upaya untuk memajukan budi pekerti (kekuatan batin), pikiran (intelek), dan jasmani anak-anak, selaras dengan alam dan masyarakatnya. ${ }^{46}$ Selanjutnya diumpai pula pendapat yang mengatakan bahwa tujuan pendidikan Islam adalah membina seluruh potensi diri manusia (jasmani, indrawi, rohani, dan akal pikiran) agar menjadi khalifah dimuka bumi. Munculnya tujuan pendidikan Islam yang demikian karena didasarkan pada tugas pokok dan fungsi manusia dalam kehidupannya didunia. Selanjutnya karena keadaan masyarakat terus berkembang dan mengalami perubahan dari waktu ke waktu maka tugas kekhalifahan tersebut akan mengalami perkembangan sesuai dengan perkembangan zaman. Selain itu pula rumusan tujuan pendidikan Islam yang diarahkan pada upaya membentuk pribadi manusia yang utama sebagai hamba Allah. Hal ini dipahami dari firman Allah yang berbunyi:

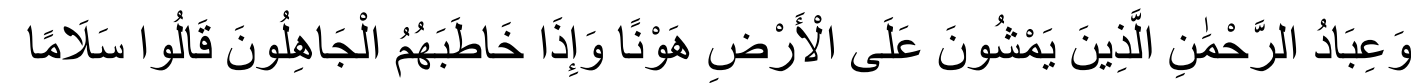

“ dan hamba-hamba yang baik dari tuhan yang penyayang itu (ialah) orangorang yang berjalan diatas bumi dengan rendah hati dan apabila orang-orang jahil menyapa mereka, mereka mengucapkan kata-kata (yang mengandung) keselamatan" (Q.S Al-Furqaan: 63)

Berfasarkan petunjuk ayat tersebut, maka seorang hamba Allah adalah orang yang ditandai dengan sifat tawaduk (rendah hati) yang timbut dari sifat yang mengagungkan Allah dan merasa demikian banyak karunia Allah berikan kepadanya, sehingga terasa sangat berutang budi dengan cara menempatkan dirinya sebagai hamba yang senantiasa patuh dan tunduk kepadanya. Sebagai hamba Allah, ia juga ditandai dengan sikapnya yang senantiasa berbuat baik kepada semua orang. Berbagai ujian, cobaan dan hinaan yang bisa saja terjadi pada dirinya yang ditimbulakn oleh orang-orang yang jahil senantiasa disikapi dengan penuh bijak dengan mencangkup kata-kata yang menimbulkan kedamaian. ${ }^{47}$ Semantara itu, krisis akhlak yang menimpa pada masyarakat umum terlihat pada sebagian sikap mereka yang dengan mudah merampas hak orang lain (menjarah), main hakim sendiri, melanggar peraturan tanpa merasa bersalah, mudah terpancing emosinya, dan sebagainya. Sedangkan krisi akhlak yang menimpa kalangan pelajar terlihat dari

\footnotetext{
${ }^{46}$ Ki Hajar Dewantara, Masalah Kebudayaan, kenang-kenangan Promosi Doktor Honoris Causa, yogyakarta, !967), 42.

${ }^{47}$ Prof. Dr. H. Abuddin Nata, M.A., Penndidikan dalam Perspektif Al-Qur'an, (Depok: Prenadamedia Group, 2016), 153.
} 
banyaknya keluhan orang tua, ahli didik, dan orang-orang yang berkecimpung dalam bidang agama dan sosial berkenaan dengan ulah sebagai pelajaran yang sukar dikendalikan, nakal, keras kepala, sering membuat keonaran, tawuran, mabukmabukan, pesta obat-obat terlarang bergaya hidup seperti hippies bahkan sudah melakukan pembajakan, pemerkosaan, pembunuhan, dan prilaku kriminal lainnya ${ }^{48}$.

Memang tidak dapat diingkari bahwa sudah sangat mendesak pendidikan karakter diterapkan di dalam lembaga pendidikan kita. Alasan-alasan kemerosotan moral, dekadensi kemanusiaan yang terjadi tidak hanya dalam diri generasi muda kita, namun telah menjadi ciri khas abad kita, seharusnya membuat kita perlu mempertimbangkan kembali bahagaimana lembaga pendidikan mampu menyumbangkan perannya bagi perbaikan kultur dengan menempatkan pendidikan karakter dalam kerangka dinamika dan dialektika proses pembentukan individu, para insan pendidik, seperti, guru, orang tua, staf sekolah, masyarakat, dan lain-lain, diharapkan semakin dapat menyadari pentingnya pendidikan karakter sebagai sarana pembentukan perilaku, pengayaan nilai individu dengan cara menyediakan ruang bagi figur keteladanan bagi anak didik dan menciptakan sebuah lingkungan yang kondusif bagi proses pertumbuhan berupa, kenyamanan, keamanan yang membantu suasana pengembangan diri satu sma lain dalam keseluruhan dimensinya (teknik, intelektual, fisikologi, moral, sosial, estetis dan religius). Pendidikan karakter lebih mengutamakan pertumbuhan moral individu yang ada dalam lembaga pendidikan. Untuk ini, dua paradigma pendidikan karakter merupakan satu keutuhan yang tidak dapat dipisahkan. Penanaman nilai dalam diri siswa, dan pembaruan tata kehidupan bersama yang lebih menghargai kebebasan individu merupakan dua wajah pendidikan karakter dalam lembaga pendidikan. Dua hal ini, jika kita integrasiskan akan menjadikan pendidikan karakter sebagai pedagogi. ${ }^{49}$

Kemampuan untuk belajar dengan cepat, kemampuan bekerja sama, kemampuan peka sosial, keberagamaan yang baik adalah hal yang dapat menjadi kekuatan untuk berdiri tegak bagi anak-anak kita. Peran guru perlu diorientasikan ke pembentukan karakter dan moral, dorong dan bantu anak-anak mempelajari materi pelajaran dengan menggunakan TIK yang sesuai dengan dunia mereka. Perubahan tatakelola pendidikan di sekolah seperti ini tentu memerlukan pemikiran bersama dari orang tua dan guru-guru di sekolah. Namun tentu bukan suatu yang mustahil dengan semangat untuk menjadikan anak-anak kita sebagai tonggak kemajuan bangsa ini dalam menyongsong Indonesia emas. Jangan salahkan mereka sebagai digital native yang berbeda dengan kita. Didiklah anak-anakmu sesuai dengan zamannya. ${ }^{50}$

Di sisi lain perkembangan dunia maya dengan dorongan dari teknologi informasi dan komunikasi (TIK) telah mengubah lingkungan belajar secara dramatis. Teknologi ini sesungguhnya telah membagi masyarakat menjadi dua generasi yang memiliki cara pandang yang berbeda. Generasi pertama adalah masyarakat yang

\footnotetext{
${ }^{48}$ Abuddin Nata, “Manajemen Pendidikan Mengatasi Pendidikan Islam Di Indonesia," Ilmu Pendidikan, 2003.

${ }^{49}$ Doni Koesoema, Pendidikan Karakter, (Jakarta: Grasindo, 2007), 135

50 Dwi Sulisworo, Dunia Digital dan Pendidikan Karakter, https://uad.ac.id/id/berita/dunia-digital-danpendidikan-karakter, 20

19: 24 April 2019
} 
dilahirkan sebelum era digital atau dikenal dengan digital immigrant. Generasi kedua dilahirkan setelah era digital atau dikenal sebagai digital native. Digital immigrant dicirikan dengan kemampuan literasi TIK yang rendah, tidak cepat menyesuaikan diri dan cenderung melihat TIK bukan suatu kebutuhan penting. Sebaliknya pada digital native memiliki literasi TIK yang tinggi, cepat menyesuaikan diri dan merasa TIK sangat penting dalam kehidupan mereka.

Dari uraian diatas kita dapat menarik benang merah bahwa tujuan pendidikan islam dalam membangun karakter siswa di era digital itu sesungguhnya bukan suatu yang asing bagi proses bersama menjadikan negri ini manusia-manusia yang tidak hanya berilmu melainkan memiliki karakter yang unggul di era yang semakin maju teknologinya.

\section{Kesimpulan}

Berdasarkan hasil penelitian di atas, maka penulis dapat merumuskan beberapa kesimpulan sebagai jawaban dari rumusan masalah. Adapun hasil kesimpulan tersebut adalah sebagai berikut:

1. Tujuan pendidikan Islam menurut Prof. Dr. H. Abuddin Nata, M.A., yaitu dapat dirumuskan untuk membina dan mengarahkan agar msnusia berpotensi untuk berbuat baik, beriman dan tunduk kepada Allah SWT. Maka dari itu tujuan pendidikan Islam diarahkan pada upaya membentuk manusia supaya memiliki akhlak dan karakter yang baik. Akhlak mulia atau karakter yang baik merupakan tujuan pokok dalam pendidikan Islam. Karakter seseorang akan dianggap baik jika perbuatannya mencerminkan nilai-nilai yang terkandung dalam Al-Quran.

2. Tujuan pendidikan Islam dalam membangun karakter siswa di era digital ini untuk memberikan arahan terhadap peserta didik tentang kemajuan teknologi yang sangat pesat dan agar tidak salah arah dalam menggunakan semua fasilitias yang disediakan pada era digital pendidikan Islam merupakan salah satu materi yang bertujuan meningkatkan akhlak mulia serta nilai-nilai spiritual dalam diri anak. 


\section{DAFTAR PUSTAKA}

Danim, Sudarwan. Media Komunikasi Pendidikan: Pelayanan Profesional Pembelajaran Dan Mutu Hasil Belajar (Proses Belajar Mengajar Di Perguruan Tinggi). Bumi Aksara, 2008.

Koesoema, Doni. Pendidikan Karakter: Strategi Mendidik Anak Di Zaman Global. Jakarta: Grasindo, 2007.

Kunandar, E, and M Si. "Guru Profesional.” Jakarta: Rajawali Pers, 2014.

Majid, Abdul, and Dian Andayani. "Pendidikan Agama Islam Berbasis Kompetensi, Bandung: PT.” Remaja Rosda Karya, 2005.

Megawangi, Ratna. "Pendidikan Karakter (Solusi Yang Tepat Untuk Membangun Bangsa).” Jakarta: Indonesia Herritage Foundation, 2004.

Miftakhu Rosyad, Ali, Darmiyati Zuchdi, Kabupaten Indramayu, and Jawa Barat. "SMP N2 Juntinyuat 2 Universitas Negeri Yogyakarta THE ACTUALIZATION OF CHARACTER EDUCATION BASED ON SCHOOL CULTURE IN SOCIAL STUDIES LEARNING IN JUNIOR HIGH SCHOOL.” Harmoni Sosial: Jurnal Pendidikan IPS 5, no. 1 (2018): 79-92. http://journal.uny.ac.id/index.php/hsjpi.

Mulyasa, H E. “Manajemen Pendidikan Karakter, Cet.” V, Jakarta: Bumi Akara, 2013, 165.

Nasution, S. Teknologi Pendidikan. Bumi Aksara, 1994.

Nata, Abuddin. "Manajemen Pendidikan Mengatasi Pendidikan Islam Di Indonesia.” Ilmu Pendidikan, 2003.

___. "Pendidikan Dalam Perspektif Al-Qur'an." Jakarta: UIN Jakarta, 2005.

Nilai-Nilai, Implementasi, and Ali Miftakhu Rosyad. "Ali Miftakhu Rosyad IMPLEMENTASI NILAI-NILAI MULTIKULTURALISME MELALUI PEMBELAJARAN PENDIDIKAN AGAMA ISLAM THE IMPLEMENTATION OF MULTICULTURALISM VALUES THROUGH LEARNING OF ISLAMIC $\begin{array}{llllll}\text { RELIGION EDUCATION” } & \text { 5, } & \text { no. } & 1 & \text { (2019). }\end{array}$ https://doi.org/10.5281/zenodo.2607388.

Nizar, Samsul. Filsafat Pendidikan Islam: Pendekatan Historis, Teoritis Dan Praktis. Ciputat Pers, 2002.

Putri, Dini Palupi. "Pendidikan Karakter Pada Anak Sekolah Dasar Di Era Digital.” AR-RIAYAH : Jurnal Pendidikan 2018. https://doi.org/10.29240/jpd.v2i1.439. 
Rosyad, Ali Miftakhu. "Al-Afkar, Journal for Islamic Studies URGENSI INOVASI PEMBELAJARAN DALAM PENDIDIKAN AGAMA ISLAM Al-Afkar, Journal for Islamic Studies THE URGENCY OF LEARNING INNOVATION ON ISLAMIC RELIGIOUS STUDY” 3, no. 1 (2019). https://doi.org/10.5281/zenodo.2546882.

Rusydi, Ibnu. "Paradigma Pendidikan Agama Integratif-Transformatif." Jurnal Pendidikan Islam, 197o. https://doi.org/10.14421/jpi.2011.11.105-120.

Samani, Muchlas. "Konsep Dan Model Pendidikan Karakter," n.d. 